\title{
PENGAR UH PENGGUNAAN TEKNIK TERATAI DALAM MENINGKATKAN KEMAMPUAN MENULIS PUISI SISWA KELAS $X$ MAS TAHFIZHIL QURAN MEDAN
}

\author{
Andi Syahputra Harahap \\ Universitas Al Washliyah Medan \\ andisyahputraharahap@gmail.com
}

\begin{abstract}
Abstrak. Penelitian ini bertujuan untuk mengetahui Pengaruh Penggunaan Teknik Teratai Dalam Meningkatkan Kemampuan Menulis Puisi Siswa Kelas X MAS Tahfizhil Quran Medan . Populasi penelitian ini adalah seluruh siswa kelas X Tahfizhil Quran Medan, yang berjumlah 88 orang dan yang menjadi sampel penelitian sebanyak 31 orang. Metode penelitian yang digunakan adalah metode eksperimen dengan model desain penelitian One Group Pre-test Post-test Design yang hanya dilaksanakan pada satu kelas (kelompok) saja. Dari pengolahan data, diperoleh nilai rata-rata pretest 64,52 , standar deviasi 6,26 , penyebaran nilai siswa terbanyak adalah 65 sebanyak 9 orang atau sekitar $29,03 \%$. Nilai rata-rata postest 73,7, standar deviasi 8,32 , penyebaran nilai siswa terbanyak adalah 75 sebanyak 7 orang atau sekitar 20,59\%. Selanjutnya, $t_{0}$ dikonsultasikan dengan tabel $\mathrm{t}$ pada taraf signifikansi 5\% dengan $\mathrm{df}=\mathrm{n}-1=31-1=30$ diperoleh taraf signifikan 5\% sebesar 2,04. Berdasarkan perhitungan yang telah dilakukan, maka dapat diketahui $t_{0}>t_{\text {tabel, }}$, yakni $4,83>2,04$. Dengan demikian $\mathrm{H}_{0}$ (hipotesis nihil) ditolak dan $\mathrm{Ha}$ (hipotesis alternatif) diterima. Hal ini membuktikan bahwa Ada Pengaruh Penggunaan Teknik Teratai dalam Meningkatkan Kemampuan Menulis Puisi Siswa Kelas X MAS Tahfizhil Quran Medan .

Kata Kunci : pengaruh, teknik teratai, menulis puisi
\end{abstract}

Abstract:This study aims to determine the effect of use of Lotus Engineering in Developing Ability Poetry Writing Class X Students MAS Tahfizhil Quran Medan in Academic Year 2020/2021. The population of this study were all students of class X MAS Tahfizhil Quran Medan, which amounted to 88 people and that a sample as many as 31 people. The research method used was experimental method to the study design models One Group Pre-test Post-test design that is only implemented in one class (group) only. From the data processing, the value of the average pretest 64.52, standard deviation 6.26, the spread of student scores highest is 65 by 9 people or about $29.03 \%$. The average value of posttest 73.7 , standard deviation 8.32, the spread of student scores highest is 75 by 7 people or about 20.59\%. After testing for normality and homogeneity do, then it transpired t0 of 4.83. Furthermore, in consultation with the table $t$ to the $5 \%$ significance level with $d f$ $=n-1=31-1=30$ obtained significant level of $5 \%$ is 2.04 . Based on the calculations that have been done, it is known t0> TTable, ie 4.83> 2.04. Thus HO (null hypothesis) is rejected and Ha (alternative hypothesis) is accepted.This proves that Ada Effects Using Lotus Engineering in Improving Students Ability Poetry Writing Class MAS Tahfizhil Quran Medan.

\section{PENDAHULUAN}

Keywords: influence, lotus technique, writing poetry
Menulis merupakan keterampilan yang sangat penting, karena dengan berbahasa tulis seseorang mampu mengungkapkan suatu gagasan. Keterampilan menulis bukanlah sesuatu yang diwariskan, tetapi hasil proses belajar dan berlatih. Oleh sebab itu, kualitas kemampuan seseorang tidak sama. Peningkatan keterampilan seseorang dapat dilakukan melalui proses belajar.

Pada hakikatnya, dalam Kurikulum 2013 diharapkan siswa mampu menulis puisi dengan baik dengan memperhatikan bait, rima dan irama. Menurut Tarigan(1983:4) Keterampilan 
menulis merupakan suatu keterampilan berbahasa yang dipergunakan untuk berkomunikasi secara tidak langsung. Berkomunikasi dengan menggunakan bahasa tulis membutuhkan keterampilan khusus, karena keterampilan menulis tidak hanya sebatas menulis karangan saja tetapi ada yang lebih membutuhkan keterampilan khusus salah satunya adalah menulis puisi. Namun pada pelaksanaannya di sekolah, siswa seringkali mengalami kesulitan dalam menuliskan puisi dengan baik.Hal ini diamati peneliti saat mengajar.

Dalam kegiatan pembelajaran, mayoritas guru kurang melibatkan siswa untuk langsung mengamati ke objek yang akan ditulis dan ini menyebabkan materi pembelajaran puisi di sekolah yang disajikan menjadi kurang menarik dan terkesan membosankan, sehingga hal itu membuat siswa merasa jenuh untuk mengikuti proses pembelajaran. Dengan demikian, dapat disimpulkan bahwa kemampuan menulis puisi masih perlu ditingkatkan. Untuk merangsang siswa agar bisa berimajinasi tentang puisi yang dihasilkannya, sebaiknya tidak memfokuskan siswa untuk berpikir statis dalam menulis puisi, melainkan membebaskan siswa untuk berimajinasi dan memberi keleluasaan dalam menentukan diksi apa yang diinginkannya.

Pembelajaran menulis puisi dapat diciptakan oleh guru dimulai dari program yang bernuansa aktif-atraktif-kreatif dan yang perlu diingat adalah dominasi pelajaran itu tetap berada pada diri siswa, sementara guru hanya sebagai fasilitator, motivator dan inspirator awal saja. Penerapan teknik pembelajaran yang sesuai dalam rangka mengoptimalkan pembelajaran menulis puisi secara aktifatraktif-kreatif dengan langsung mengamati objek yang akan ditulis. Menulis puisi dalam penelitian ini adalah dengan menggunakan Teknik Teratai ( terjun, amati, rangkai), adapun teknik teratai menurut Suryani dalam skripsi UPI (Universitas Pendidikan Indonesia) sangat efektif dalam pembelajaran menulis puisi. Dalam teknik ini terdapat tiga kegiatan dasar, sesuai dengan nama teknik tersebut. Ter; terjun, at; amati, ai; rangkai. Terjun mengandung pengertian siswa langsung ke objek yang akan diamati. Amati mengandung pengertian, siswa melakukan pengamatan langsung terhadap berbagai objek di alam sekitar. Rangkai, setelah siswa selesai mengamati dan menentukan apa-apa saja yang nanti akan dijadikannya sebagai bahan penciptaan puisi, selanjutnya siswa mulai menyusun dan merangkainya menjadi sebuah puisi. Dengan demikian, teknik teratai menawarkan kegiatan pembelajaran yang menyenangkan, bermakna dan tidak mengabaikan keaktifan siswa sebagai pondasi utamanya.Teknik Teratai ini lebih menekankan siswa untuk aktif, dinamis dan berlaku sebagai subjek.Namun bukan berarti guru harus pasif, guru berperan sebagai pemandu yang penuh dengan motivasi, pandai berperan sebagai mediator dan kreatif.Konteksnya adalah siswa menjadi tumpuan utama.

Dalam proses pembelajaran menulis puisi, Teknik Teratai ini lebih menekankan pada wujud kreatifitas siswa dalam mengekspresikan pikiran dan perasaan sesuai dengan objek yang diamatinya. Hal itu dapat membantu dalam menemukan ide-ide yang kreatif dan penggunaan diksi yang tepat, sehingga memudahkan siswa untuk menulis puisi dengan baik.

Teknik Teratai memungkinkan siswa lebih bersemangat dan lebih berekspresi dalam belajar menulis puisi. Sehingga di akhir proses pembelajaran, tujuan pembelajaran dapat tercapai dan bisa dijadikan pilihan sebagai salah satu teknik pembelajaran yang dapat digunakan untuk mengatasi masalah tersebut. Berdasarkan latar belakang masalah di atas, maka peneliti tertarik melakukan penelitian dengan judul "Pengaruh Penggunaan Teknik Teratai dalam Meningkatkan Kemampuan Menulis Puisi Siswa Kelas X MAS Tahfizhil Quran Medan"

\section{METODE PENELITIAN}

Sesuai dengan masalah dan tujuan penelitian maka metode yang digunakan dalam penelitian ini adalah metode eksperimen. Hal ini sejalan dengan pendapat Arikunto (2006:207) yang menyatakan bahwa, "Penelitian eksperimen merupakan penelitian yang dimaksudkan untuk mengetahui ada tidaknya akibat dari sesuatu yang dikenakan pada subjek selidik."

Adapun metode yang digunakan dalam penelitian ini adalah metode 
Pengaruh Penggunaan Teknik Teratai dalam Meningkatkan Kemampuan Menulis Puisi Siswa Kelas X MAS Tahfizhil Quran Medan

eksperimen dengan model one group pretest post-test design. Penelitian ini dilakukan untuk mengetahui Pengaruh Teknik Teratai dalam Meningkatkan Kemampuan Menulis Puisi.

Tabel model one group pre-test post-test design menurut Arikunto:

Tabel 1. Desain Eksperimen One Group

\begin{tabular}{|c|c|c|c|} 
Pre-Test Post-Test \\
\hline Kelas & Pretest & Perlakuan & Posttest \\
\hline Eksperimen & $\mathrm{O}_{1}$ & $\mathrm{X}$ & $\mathrm{O}_{2}$ \\
\hline
\end{tabular}

Keterangan:

$\mathrm{O}_{1}=$ Pre-test (tes awal) menulis puisi

$\mathrm{X}=$ Perlakuan dengan Teknik Teratai

$\mathrm{O}_{2}=$ Post-test $($ tes akhir) menulis puisi

\section{Instrumen Penelitian}

Berikut ini penilaian yang digunakan Waluyo (1987:101) dalam melakukan penilaian terhadap kemampuan menulis puisi.

Tabel 2. Kisi-Kisi Penilaian Keterampilan Menulis Puisi Tema Lingkungan Sekitar Sekolah

\begin{tabular}{|c|c|c|c|}
\hline $\mathbf{N}$ & $\begin{array}{c}\text { Indikat } \\
\text { or }\end{array}$ & Prediktor & Skor \\
\hline 1 & Tema & $\begin{array}{l}\text { Tema puisi } \\
\text { keadaan } \\
\text { lingkungan } \\
\text { sekitar sekolah. } \\
\text { a. } \\
\text { Menggunakan } \\
\text { nama-nama } \\
\text { tempat (kantin, } \\
\text { pos satpam, } \\
\text { parkiran, } \\
\text { lapangan) } \\
\text { b. } \\
\text { Menggunakan } \\
\text { nama-nama } \\
\text { hewan disekitar } \\
\text { sekolah seperti } \\
\text { semut, lalat, } \\
\text { belalang dan } \\
\text { lain-lain } \\
\text { c. } \\
\text { Menggunakan } \\
\text { nama-nama } \\
\text { tumbuhan yang } \\
\text { berada disekitar } \\
\text { sekolah seperti } \\
\text { pohon, bunga, } \\
\text { dan lain-lain }\end{array}$ & $\begin{array}{l}\text { Isi sesuai } \\
\text { dengan tema } \\
\text { mendapat } \\
\text { skor } \mathbf{2 0} \text {, isi } \\
\text { cukup sesuai } \\
\text { dengan tema } \\
\text { mendapat } \\
\text { skor } \mathbf{1 5} \text {, isi } \\
\text { kurang sesuai } \\
\text { dengan tema } \\
\text { mendapat } \\
\text { skor } \mathbf{1 0} \text {, isi } \\
\text { tidak sesuai } \\
\text { dengan tema } \\
\text { mendapat } \\
\text { skor } \mathbf{5} \text {. }\end{array}$ \\
\hline 2 & $\begin{array}{l}\text { Pemiliha } \\
\text { n Diksi }\end{array}$ & $\begin{array}{l}\text { Fenomena atau } \\
\text { kondisi yang } \\
\text { terjadi pada } \\
\text { objek } \\
\text { (lingkungan). } \\
\text { Salah satunya } \\
\text { dibawah ini: } \\
\text { a. Misalnya } \\
\text { bunga, } \\
\text { fenomenanya } \\
\text { yakni: warna } \\
\text { bunga, bentuk, } \\
\text { dan wangi } \\
\text { bunga } \\
\text { b. Misalnya } \\
\text { kantin, pos } \\
\text { satpam, } \\
\text { parkiran, } \\
\text { lapangan. } \\
\text { fenomenanya } \\
\text { yakni: bentuk, } \\
\text { ramai, sejuk, }\end{array}$ & $\begin{array}{l}\text { Pemilihan } \\
\text { diksi tepat } \\
\text { mendapat } \\
\text { skor 20, } \\
\text { pemilihan } \\
\text { diksi cukup } \\
\text { tepat } \\
\text { mendapat } \\
\text { skor 15, } \\
\text { pemilihan } \\
\text { diksi kurang } \\
\text { tepat } \\
\text { mendapat } \\
\text { skor 10, } \\
\text { pemilihan } \\
\text { diksi tidak } \\
\text { tepat } \\
\text { mendapat } \\
\text { skor } \mathbf{5} \text {. }\end{array}$ \\
\hline
\end{tabular}

\begin{tabular}{|c|c|c|c|}
\hline & & rindang. & \\
\hline 3 & $\begin{array}{l}\text { Gaya } \\
\text { Bahasa }\end{array}$ & 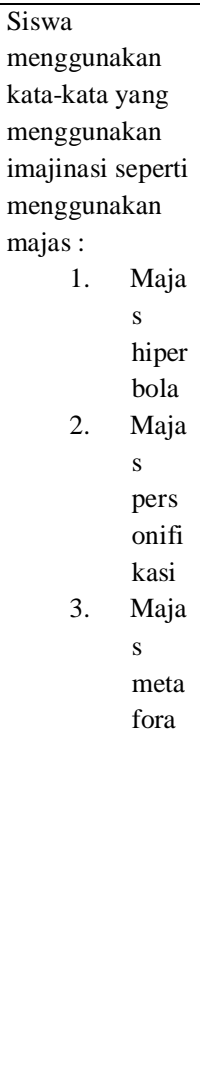 & $\begin{array}{l}\text { Menggunaka } \\
\text { n banyak } \\
\text { gaya bahasa } \\
\text { dengan tepat } \\
\text { penggunaann } \\
\text { ya mendapat } \\
\text { skor 20, } \\
\text { banyak } \\
\text { menggunaka } \\
\text { n gaya } \\
\text { bahasa } \\
\text { namun } \\
\text { kurang tepat } \\
\text { penggunaann } \\
\text { ya mendapat } \\
\text { skor } \mathbf{1 5} \text {, } \\
\text { sedikit } \\
\text { menggunaka } \\
\text { n gaya } \\
\text { bahasa dan } \\
\text { tepat } \\
\text { penggunaann } \\
\text { ya mendapat } \\
\text { skor } \mathbf{1 0} \text {, tidak } \\
\text { menggunaka } \\
\text { n gaya } \\
\text { bahasa } \\
\text { mendapat } \\
\text { skor } \mathbf{5} \text {. }\end{array}$ \\
\hline 4 & Rima & $\begin{array}{l}\text { a. } \\
\text { Menggunakan } \\
\text { rima akhir } \\
\text { (persamaan } \\
\text { bunyi pada } \\
\text { akhir baris) } \\
\text { b. } \\
\text { Menggunakan } \\
\text { rima datar } \\
\text { (persamaan } \\
\text { bunyi pada tiap- } \\
\text { tiap larik sajak) }\end{array}$ & $\begin{array}{l}\text { Penggunaan } \\
\text { rima tepat } \\
\text { mendapat } \\
\text { skor } \mathbf{2 0} \text {, } \\
\text { penggunaan } \\
\text { rima cukup } \\
\text { tepat } \\
\text { mendapat } \\
\text { skor } \mathbf{1 5} \text {, } \\
\text { penggunaan } \\
\text { rima kurang } \\
\text { tepat } \mathbf{1 0} \text {, } \\
\text { penggunaan } \\
\text { rima tidak } \\
\text { tepat } \mathbf{5} \text {. }\end{array}$ \\
\hline 5 & Amanat & $\begin{array}{l}\text { a. Hendaknya } \\
\text { setiap orang } \\
\text { menjaga dan } \\
\text { melestarikan } \\
\text { lingungan } \\
\text { sekolah } \\
\text { b. kebersihan } \\
\text { dan keindahan } \\
\text { merupakan } \\
\text { sebagian dari } \\
\text { iman } \\
\text { c. Nikmati dan } \\
\text { jangan sia- } \\
\text { siakan } \\
\text { keindahan alam } \\
\text { yang ada } \\
\text { disekitarmu }\end{array}$ & $\begin{array}{l}\text { jika terdapat } \\
\text { amanat dan } \\
\text { sesuai dengan } \\
\text { isi puisi } \\
\text { mendapat } \\
\text { skor } \mathbf{2 0} \text {, jika } \\
\text { terdapat } \\
\text { amanat } \\
\text { namun } \\
\text { kurang sesuai } \\
\text { dengan isi } \\
\text { puisi } \\
\text { mendapat } \\
\text { skor } \mathbf{1 0} \text {, jika } \\
\text { tidak terdapat } \\
\text { amanat } \\
\text { mendapat } \\
\text { skor } \mathbf{5} \text {. }\end{array}$ \\
\hline & & & $\begin{array}{l}\text { Jumlah Skor } \\
100\end{array}$ \\
\hline
\end{tabular}

Teknik Analisis Data

\section{Uji Normalitas Variabel Penelitian}

Uji kenormalan dilakukan secara parametrik dengan menggunakan penaksir rata-rata pada simpangan baku. Uji yang digunakan adalah uji Lilifors. Misalkan kita mempunyai sampel acak dengan hasil pengamatan $x_{1}, x_{2}, \ldots x_{n}$. Berdasarkan sampel ini akan diuji hipotesis nol bahwa 
sampel tersebut berasal dari populasi berdistribusi normal melawan hipotesis tandingan bahwa hipotesis tidak normal. Untuk pengujian hipotesis nol tersebut, kita tempuh prosedur sebagai berikut:

1) pengamatan $x_{1}, x_{2}, \ldots x_{n}$ dijadikan bilangan baku $z_{1}, z_{2}, \ldots z_{n}$ dengan mengunakan rumus $z_{1}=\frac{x_{1-} \bar{x}}{s}(\bar{x}$ dan $s$ masing-masing merupakan rata-rata dan simpangan baku sampel),

2) untuk tiap bilangan baku ini menggunakan daftar distribusi narmal baku kemudian dihitung $F\left(z_{i}\right)=P\left(z \leq z_{i}\right)$,

3) selanjutnya dihitung proporsi $z_{1}, z_{2}, \ldots z_{n}$ yang lebih kecil atau sama sengan $z_{i}$ jika proporsi ini dinyatakan oleh $_{S\left(z_{i}\right)}$, maka

$S\left(z_{i}\right)=\frac{\text { banyaknya } z_{1}, z_{2}, \ldots z_{n}}{n}$

4) dihitung selisih $F\left(z_{i}\right)-S\left(z_{i}\right)$ kemudian tentukan harga mutlaknya, dan

5) ambil harga yang paling besar di antara harga-harga mutlak selisih tersebot (Lo).

\section{Uji homogenitas}

Pemeriksaan uji homogenitas dilakukan untuk mengetahui apakah ada sampel yang diambil varians yang homogenitas atau tidak. Untuk uji homogenitas digunakan rumus:

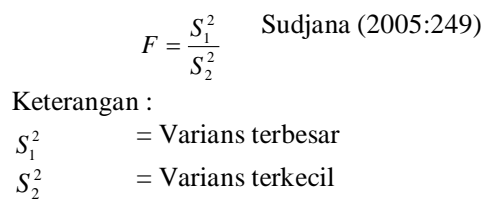

Pengujian homogenitas dilakukan dengan kriteria: $\mathrm{H}_{\mathrm{o}}$ diterima jika $\mathrm{F}_{\text {hitung }}<$ $F_{\text {tabel }}$ dan $\mathrm{H}_{\mathrm{o}}$ ditolak jika $\mathrm{F}_{\text {hitung }}>\mathrm{F}_{\text {tabel }}$ yang menyatakan bahwa sampel berasal dari populasi yang homogen.

\section{Pengujian hipotesis}

Uji hipotesis dilakukan dengan menggunakan uji " $t$ ".Pengujian hipotesis dilakukan dengan membandingkan " $t_{0}$ " dengan $t_{\text {tabel. }}$. Jika $t_{0}>t_{\text {tabel }}$ maka $\mathrm{H}_{0}$ ditolak dan $\mathrm{H}_{\mathrm{a}}$ diterima, artinya Teknik Teratai lebih efektif digunakan untuk meningkatkan kemampuan menulis puisi.

Sedangkan $t_{0}<t_{\text {tabel }}$ maka $\mathrm{H}_{0}$ diterima dan $\mathrm{H}_{\mathrm{a}}$ ditolak, artinya Teknik Teratai tidak lebih efektif digunakan untuk meningkatkan kemampuan menulis puisi.

Uji hipotesis penelitian dilakukan dengan menggunakan uji " $\mathrm{t}$ " dengan rumus sebagai berikut:

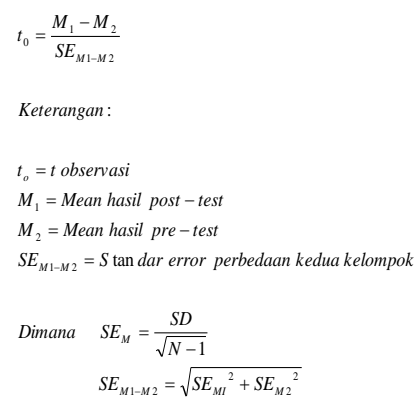

Sudijono (2009:284)

Dengan demikian, jika $t_{0}<t_{t}$ pada taraf nyata $\alpha=0,05$ maka Ho diterima dan Ha ditolak sebaliknya jika $t_{\mathrm{o}}>\mathrm{t}_{\mathrm{t}}$ pada taraf nyata $\alpha=0,05$ maka Ho ditolak dan $\mathrm{Ha}$ diterima.

\section{HASIL PENELITIAN}

1. Analisis data kemampuan menulis puisi sebelum teknik teratai (terjun, amati, rangkai) diterapkan

Dari hasil analisis data diperoleh nilai rata-rata atau Mean sebesar 64,52; Standar Deviasi = 6,26; dan Standar Error $=1,14$. Data kelas eksperimen di atas dapat dikategorikan menjadi tiga kategori, yaitu sangat baik, baik, dan cukup.Adapun ketentuan dalam pengkategorian data tersebut adalah sebagai berikut.

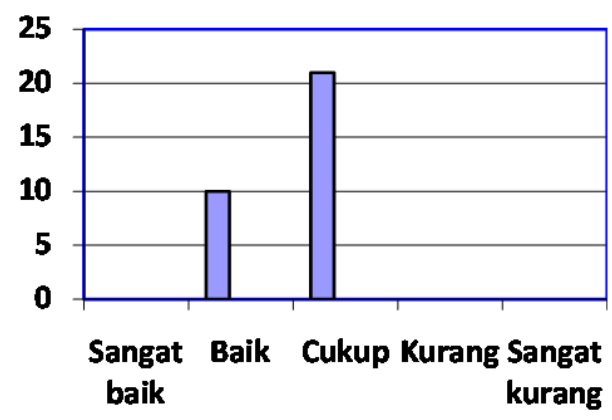

2. Analisis data kemampuan menulis puisi sesudah teknik teratai (terjun, amati, rangkai) diterapkan

Berdasarkan hasil analisis data diperoleh nilai rata-rata hasil belajar menulis puisi siswa sesudah teknik teratai (terjun,amati,rangkai) diterapkan maka dapat disimpulkan bahwa yang termasuk kategori sangat baik sebanyak 5 orang atau $16,12 \%$, kategori baik sebanyak 18 orang atau $58,06 \%$, kategori cukup sebanyak 8 orang atau $25,80 \%$, sementara kategori kurang dan sangat kurang tidak ada sama sekali atau 0\%. Penyebaran nilai siswa dapat dilihat pada grafik berikut.

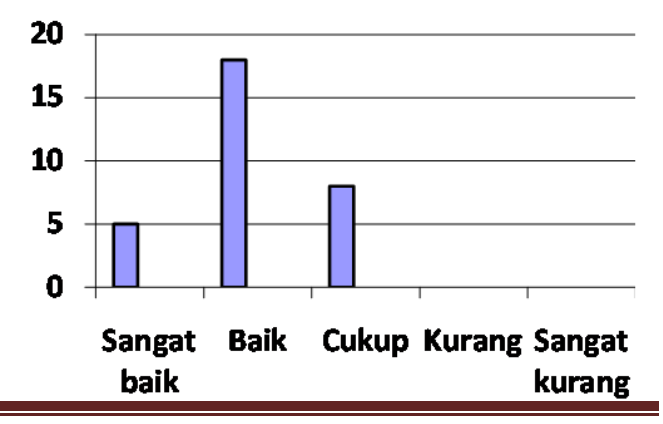




\section{Uji Normalitas}

a. Uji normalitas hasil kemampuan menulis puisi sebelum teknik teratai (terjun, amati, rangkai)diterapkan

Berdasarkan hasil analisis data diperoleh harga $\mathrm{L}_{\text {hitung }}([\mathrm{F}(\mathrm{Zi})-\mathrm{S}(\mathrm{Zi})])$ yang paling besar, sehingga dari tabel diatas diperoleh $\mathrm{L}_{\text {hitung }}=-0,1513$. Dari daftar uji liliefors dengan taraf nyata $\alpha=0,05$ dengan $\mathrm{N}=31$ maka diperoleh harga $\mathrm{L}_{\text {tabel }}=0,1593$. Dengan demikian, $\left.\mathrm{L}_{\text {hitung }}<\mathrm{L}_{\text {tabel }}-0,1513<0,1593\right)$. Hal ini menunjukkan bahwa data variabel $\mathrm{X}$ berdistribusi normal.

b. Uji normalitas hasil kemampuan menulis puisi sesudah teknik teratai ( terjun, amati, rangkai)diterapkan

Berdasarkan hasil analisis data diperoleh harga $\mathrm{L}_{\text {hitung }}([\mathrm{F}(\mathrm{Zi})-\mathrm{S}(\mathrm{Zi})])$ yang paling besar, sehingga dari tabel diatas diperoleh $\mathrm{L}_{\text {hitung }}=-0,1216$. Dari daftar uji liliefors dengan taraf nyata $\alpha=0,05$ dengan $\mathrm{N}=34$ maka diperoleh harga $\mathrm{L}_{\text {tabel }}=0,1593$. Dengan demikian, $\mathrm{L}_{\text {hitung }}<\mathrm{L}_{\text {tabel }}(-0,1216<0,1593)$. Hal ini menunjukkan bahwa data variabel $\mathrm{X}$ berdistribusi normal.

\section{Uji Homogenitas}

Berdasarkan hasil analisis diketahui bahwa $\mathrm{F}$ tabel adalah 1,84, sementara harga $F_{\text {hitung }}$ adalah 1,76. Harga $F_{\text {hitung }}$ dibandingkan dengan $F_{\text {tabel }}$ maka dipeeroleh $F_{\text {hitung }}<F_{\text {tabel }}$ atau 1,76 $<1,84$ sehingga dapat disimpulkan bahwa sampel berasal dari kelompok yang homogen.

\section{Pengujian Hipotesis}

Berdasarkan hasil analisis data, nilai tersebut akan dikonsultasikan dengan tabel $\mathrm{t}$ pada taraf signifikansi $5 \%$ dengan $\mathrm{df}=\mathrm{N}-1=31-1=30$ diperoleh taraf signifikan 5\% sebesar 2,04. Berdasarkan perhitungan yang telah dilakukan, maka dapat diketahui $t_{0}>t_{\text {tabel}}$, yakni 4,83> 2,04. Dengan demikian $\mathrm{H}_{0}$ (hipotesis nihil) ditolak dan $\mathrm{Ha}$ (hipotesis alternatif) diterima.Hal ini membuktikan bahwa Ada Pengaruh Penggunaan Teknik Teratai dalam Meningkatkan Kemampuan Menulis Puisi Siswa Kelas X MASTahfizhil Quran Medan.

\section{PEMBAHASAN}

Setelah melakukan prosedur penelitian seperti melakukan analisis data, melakukan pengujian hipotesis, hingga akhirnya peneliti mendapatkansuatu hasil yang positif dalam meningkatkan kemampuan menulis puisi siswa. Teknik teratai (terjun, amati, rangkai) yang diberikan pada siswa kelas X SMA AlUlum Terpadu Medan dalam meningkatkan kemampuan menulis puisi ternyata memiliki pengaruh yang signifikan. Hal ini dapat dibuktikan dari hasil penelitian yang menunjukkan nilai rata-rata kemampuan menulis puisi sesudah menggunakan teknik teratai (terjun, amati, rangkai), lebih tinggi yakni sebesar 73,7 (kategori baik) dan simpangan baku sebesar 8,31 daripada nilai rata-rata kemampuan menulis puisi tanpa menggunakan teknik teratai (terjun, amati, rangkai), yakni sebesar 64,52 (kategori cukup) dan simpangan baku sebesar 6,26.

Sebelum teknik teratai (terjun, amati, rangkai) diterapkan, Hasil penilaian indikator tema yaitu 16 orang $(51,6 \%)$ memperoleh skor maksimal 20, sebanyak 7 orang $(22,56 \%)$ memperoleh skor 15 dan ada sebanyak 8 orang $(25,8 \%)$ yang memperoleh skor 10. Hasil penilaian indikator diksi yaitu 8 orang $(25,8 \%)$ memperoleh skor maksimal 20, sebanyak 18 orang $(58,1 \%)$ memperoleh skor 15 dan ada sebanyak 5 orang $(16,1 \%)$ yang memperoleh skor 10. Hasil penilaian indikator gaya bahasa yaitu tidak ada seorang pun $(0 \%)$ yang memperoleh skor maksimal 20, sebanyak 6 orang $(19,36 \%)$ memperoleh skor 15 , sebanyak 9 orang (29\%) yang memperoleh skor 10, dan ada sebanyak 16 orang $(51,6 \%)$ yang memperoleh skor 5. Hasil penilaian indikator diksi yaitu 4 orang (12,9\%) memperoleh skor maksimal 20, sebanyak 16 orang $(51,6 \%)$ memperoleh skor 15 dan ada sebanyak 11 orang $(35,5 \%)$ yang memperoleh skor 10. Hasil penilaian indikator amanat yaitu 4 orang (12,9\%) yang memperoleh skor maksimal 20, sebanyak 22 orang $(70,97 \%)$ memperoleh skor 10, dan ada sebanyak 5 orang $(16,13 \%)$ yang memperoleh skor 5 .

Sesudah teknik teratai (terjun, amati, rangkai) diterapkan, Hasil penilaian indikator tema yaitu 25 orang $(80,6 \%)$ memperoleh skor maksimal 20, dan ada sebanyak 6 orang $(19,4 \%)$ yang memperoleh skor 10. Hasil penilaian indikator diksi yaitu 16 orang $(51,6 \%)$ memperoleh skor maksimal 20, sebanyak 10 orang $(32,3 \%)$ memperoleh skor 15 dan ada sebanyak 5 orang $(16,1 \%)$ yang 
memperoleh skor 10. Hasil penilaian indikator gaya bahasa yaitu 2 orang $(6,4 \%)$ yang memperoleh skor maksimal 20, sebanyak 9 orang $(29 \%)$ memperoleh skor 15 , sebanyak 10 orang $(32,3 \%)$ yang memperoleh skor 10, dan ada sebanyak 10 orang $(32,3 \%)$ yang memperoleh skor 5 . Hasil penilaian indikator diksi yaitu tidak ada seorang pun $(0 \%)$ yang memperoleh skor maksimal 20, sebanyak 18 orang $(58,1 \%)$ memperoleh skor 15 dan ada sebanyak 13 orang $(41,9 \%)$ yang memperoleh skor 10.

Hasil perhitungan hipotesis tersebut menyatakan bahwa adanya Pengaruh Penggunaan Teknik Teratai Dalam Meningkatkan Kemampuan Menulis Puisi Siswa Kelas X MASTahfizhil Quran Medan . Hal ini disebabkan karena teknik teratai memberikan kesempatan kepada siswa untuk memperoleh daya inspirasi atau imajinasi yang dimilikinya dengan mengembangkan segala potensi yang dimilikinya melalui langsung mengamati objek yang akan dibuatnya menjadi bentuk tulisan yang indah yaitu puisi sehingga siswa dapat memperoleh tema, diksi, gaya bahasa, rima, dan amanat yang sesuai dengan yang diharapkan sebelumnya.

Dari penjelasan di atas, maka dapat disimpulkan bahwa kemampuan siswa dalam menulis puisi meningkat dengan menggunakan teknik teratai (terjun, amati, rangkai). Dengan demikian teknik teratai berpengaruh positif dalam meningkatkan kemampuan menulis puisi oleh siswa kelas X MASTahfizhil Quran Medan .

\section{SIMPULAN}

Berdasarkan hasil penelitian yang telah diuraikan sebelumnya, maka disimpulkan hal-hal sebagai berikut.

1. Kemampuan menulis puisi siswa kelas X MASTahfizhil Quran Medan sebelum menggunakan teknik teratai (terjun, amati, rangkai) berada pada nilai rata-rata 64,52.

2. Kemampuan menulis puisi siswa kelas X MASTahfizhil Quran Medan sesudah menggunakan teknik teratai (terjun, amati, rangkai) berada pada nilai rata-rata 73,7 .

3. Ada Pengaruh Penggunaan Teknik Teratai dalam Meningkatkan Kemampuan Menulis Puisi Siswa Kelas X MASTahfizhil Quran Medan .

\section{SARAN}

Berdasarkan kesimpulan di atas, maka sebagai tindak lanjut penelitian ini perlu diuraikan beberapa saran berikut ini.

1. Berdasarkan hasil penelitian, teknik teratai (terjun, amati, rangkai) memiliki pengaruh yang signifikan dalam meningkatkan kemampuan siswa dalam menulis puisi. Oleh karena itu, teknik pembelajaran ini dapat dijadikan sebagai salah satu alternatif pembelajaran dalam proses belajar-mengajar di kelas.

2. Perlu dilakukan penelitian lanjutan oleh peneliti lain guna meningkatkan kemampuan siswa dalam menulis puisi khususnya dalam meningkatkan kemampuan berpikir siswa dengan sungguh-sungguh memperhatikan minat siswa dan jika peneliti lanjutan ingin menggunakan teknik pembelajaran ini hendaknya mencoba materi lain yang dianggap sesuai demi keefektifan penggunaan teknik pembelajaran ini.

\section{DAFTAR PUSTAKA}

Arikunto, Suharsimi. 2006. Prosedur Penelitian Suatu Pendekatan Praktik. Jakarta : Rineka Cipta.

Nazir. 2003. Metode Penelitian. Jakarta : Ghalia Indonesia

Sudijono, Anas. 2009. Pengantar Statistik Pendidikan. Jakarta : RajawaliPers.

Sudjana.2005. Metoda Statistika.Bandung : Tarsito.

-----------. 2001. Metode dan Teknik

Pembelajaran Partisipatif.

Bandung. Falah production.

Suryani.Efektivitas Penggunaan Teknik

Teratai Dalam Meningkatkan

Kemampuan Menulis Puisi Pada

Siswa Kelas X SMA Negeri 6

Cimahi Tahun Ajaran

2009/2010.Skripsi.UPI.

Wiji Astuti, Wahyu. 2011. Efektivitas Strategi Pohon Jaringan Dalam Meningkatkan Kemampuan Menulis Puisi Siswa Kelas X SMA Nusantara Lubuk Pakam Tahun Ajaran 2011/2012.Skripsi.UNIMED. 